\title{
Gully erosion: a comparison of contributing factors in two catchments in South Africa
}

\author{
Ndifelani Mararakanye ${ }^{\mathrm{a}, \mathrm{b}}$ and Paul D. Sumner ${ }^{\mathrm{a}}$ * \\ ${ }^{a}$ Department of Geography, Geoinformatics and Meteorology, University of Pretoria, Private Bag X20, Hatfield, \\ 0028, South Africa. \\ ${ }^{\mathrm{b}}$ Directorate: Information Services, Department of Agriculture, Rural Development, Land and Environmental \\ Affairs, Private Bag X9019, Ermelo, 2350, South Africa.
}

\section{Highlights}

- Gully formation is associated with duplex soils on colluvium and al luvial deposits

- Hutton soil and Lithosols developed on granite rocks may control gully distribution

- Gully erosion propensity increases rapidly for hillslopes steeper than $4.5^{\circ}$

- Contributing factors for gullies varied between two adjacent third order catchments

\begin{abstract}
Gully erosion is an environmental, agricultural and social problem requiring extensive research and mitigation actions to control. This study assesses the influence of factors contributing to gully erosion using Geographic Information System (GIS) and Information Value (InfVal) statistics from two catchments coded X12 and W55 in the Mpumalanga province of South Africa. Existing spatial data representing contributing factors; soil, geology, vegetation and land use were analyzed. Topographic variables were extracted from a 10 m Digital Elevation Model (DEM) interpolated from map contours, and gullies were mapped from aerial photos with $0.5 \mathrm{~m}$ spatial resolution. A zonal approach was used to extract the proportion of gullies in each of the contributing factor classes using GIS software packages, and InfVal weighting was performed to determine the influence of each class. Comparison of the results
\end{abstract}

\footnotetext{
* Corresponding author Tel.: +2712 $4203536 / 5966$.

E-mail address: paul.sumner@up.ac.za.
} 
shows the variation in the level of influence of factors contributing to gully erosion. The findings in catchment X12 support a commonly held assumption that gully formation is influenced by duplex soils underlain by colluvium and alluvial deposits on a lower slope position where overland flow converges and accumulates, resulting in high soil moisture. Gullies were also influenced by soils developed over weathered granite, gneiss and ultramafic rocks. The influence of a granite rock was further highlighted in catchment W55 where there is a variable thickness of very deep Hutton dominant soil form and shallow Lithosols with sandy texture, on an area of moderate to steep slopes where overland flow converges and accumulates, with high stream power in overgrazed grassland. An understanding of these factors will assist future modeling of the vulnerability to gully erosion over a wider geographical area.

Key words: Gully erosion, Contributing factors, Geographic Information System, Information Value method, South Africa

\section{Introduction}

Globally, soil erosion is recognized as one of the most serious environmental problems threatening human populations (Lal, 2001; Valentin et al., 2005; Jahantigh and Pessarakli, 2011). Many regions of the world, such as the southwestern United States, Mediterranean, Australia and Africa, are characterized by severe forms of water and wind erosion (Lyons et al., 2013). Water erosion is the most dominant phenomenon in South Africa (SA) in terms of its impact on soil degradation (Laker, 2004; Le Roux et al., 2008) and it is most discernible in the form of gullies which scar large parts of the Eastern Cape (EC) and KwaZulu Natal (KZN), the Karoo region of the Northern Cape (NC) and parts of the Free State (FS), Limpopo (LP), Mpumalanga (MP), Western Cape (WC) and North West (NW) provinces (Mararakanye and Le Roux, 2012). Gullies are deeply incised erosion channels larger than rills and are characterized by steep sidewalls, stepped longitudinal profiles and actively eroding head scarps (Bradford and Piest, 1980; Poesen 
et al., 1996, 2003; Salleh and Mousazadeh, 2011). Gullies pose a threat to agriculture, environmental sustainability and rural community livelihoods, and produce a considerable quantity of sediment, that infills downstream reservoirs (Vandekerckhove et al., 2000). The loss of top soil through gullying affects agricultural crop production (e.g. Oldeman, 1993; Marker and Sidorchuk, 2003; Casali et al., 2009; Kakembo et al., 2009). Gullies may also cause damage to infrastructure such as roads, bridges, buildings and pipes (Nwilo et al., 2011), lowers ground water levels, impedes access to land and contaminates water bodies (Valentin et al., 2005; Imasuen et al., 2011). Numerous factors contribute to gully erosion development including soil, geology, rainfall, topography, vegetation and land use (Liggitt and Fincham, 1989; Kakembo et al., 2009; Le Roux and Sumner, 2012). In order to successfully develop control and prevention measures for gully erosion, the influence these factors must first be quantified.

This study seeks to quantify and compare the influence of various biophysical factors and land use activities on gully erosion in two tertiary or third order catchments of the South African Department of Water Affairs and Forestry (DWAF) hierarchical catchment subdivision system (see Middleton and Bailey, 2008). The catchments are located within the unique geological environment of MP province, SA. Most research on gullies in SA was conducted in the EC and KZN regions on a geological setting dominated by sandstone, mudstone and siltstone of the Karoo Supergroup (e.g. Kakembo et al., 2009; Le Roux and Sumner, 2012) as well as alluvium or colluvium deposits (e.g. Rienks et al., 2000; Lyons et al., 2013), whereas little information exists in other regions of the country. The main problem is that contributing factors important in one region do not necessarily have the same level of significance in other regions (Sonneveld et al., 2005). Contributing factors have mainly been studied through experimental plots, field and laboratory based analysis suitable for local scale assessment (e.g. Dardis and Beckedahl, 1991; 
Rienks et al., 2000; Chaplot et al., 2011; Grellier et al., 2012). While the accuracy and value of data associated with field and experimental plot methods is highly appreciated, they are generally not appropriate for regional scale assessments where research is required to inform policies and regulations as well as allocation of scarce conservation resources (Vrieling, 2006). Generalization based on the results of field measurements and experimental plot has a potential flaw, particularly since it has been previously demonstrated that sediment yield and hence the implication thereof decreases with an increase in the geographical extent of the area studied (Poesen et al., 2003). Application of Geographical Information System (GIS) and remote sensing approaches has the potential to monitor and assess the contributing factors over a broader spatial scale. Extensive use of these approaches in studying contributing factors in the EC region has been demonstrated by Kakembo et al. (2009) and Le Roux and Sumner (2012). However, regional data availability remains a challenge.

A combination of GIS and bivariate statistics in a form of Information Value (InfVal) weight has the potential to quantitatively express the influence of each contributing factor on gully development. The InfVal has frequently been applied to study the susceptibility of various biophysical and land use factors to landslides (e.g. Van Westen, 1993; Rautela and Lakhera, 2000; Zezere, 2002) - a phenomenon which is often associated with gullying (Pradhan et al., 2012). Recently, InfVal has also been included in gully erosion susceptibility studies (e.g. Conforti et al., 2011; Luca et al., 2011). The main drawbacks of InfVal are that the influence of factors is considered independently, whereas in reality some interdependency between factors may exist (Van Westen et al., 1997) and the accuracy of the statistics depends on the quality of data (Nandi and Shakoor, 2009). In this context, the aim of this study is to apply GIS and InfVal statistics to investigate the influence of various contributing factors on gully erosion from two 
adjacent tertiary catchments in a region that has not been subjected to extensive soil erosion research. The main objectives were to map gully erosion features, to improve the topographic variables datasets and then to assess, quantify and compare the dominant contributing factors.

\section{Study area}

The study area consists of two tertiary catchments located in the MP province of SA (Fig. 1). Coded X12 and W55 by the DWAF, the catchments form part of the Komati and Usutu Rivers (see Midgley et al., 1994; Middleton and Bailey, 2008) and have areas of approximately 2559 and $1870 \mathrm{~km}^{2}$ respectively. These catchments are located in a sediment yield region with erodibility indices ranging from 5 to $723 \mathrm{t} \mathrm{km}^{2} \mathrm{a}^{1}$ (see Rooseboom et al., 1992). High sediment yield in this region is due to widespread gully erosion particularly further afield of the study area in the Mfolozi drainage basin where severe gullies have been reported (e.g. Liggitt and Fincham, 1989; Watson et al., 1996; Watson and Ramokgopa, 1997; Watson, 2000). The national gully location map of Mararakanye and Le Roux (2012) shows a high gully density in catchment X12 compared to catchment W55. This variation presents an opportunity to study and compare the influence of various factors controlling gully erosion in the two catchments.

The geology of the two catchments varies (see Fig. 1) and hence variation in the soils formed thereof. Catchment W55 is underlain by the Randian age granite rocks, dolerites intrusive rocks, shale, sandstone and coal beds (Vryheid formation) of the broader Karoo Supergroup and in parts, the Quaternary unconsolidated sediments (Geological Survey, 1986a). Randian age granite rocks, Vryheid formation and Quaternary unconsolidated sediments also occur in catchment $\mathrm{X} 12$, but large part is mainly underlain by ultramafic rocks, granite and gneiss rocks and minor sediments such as banded iron formation, chert, quartzite, conglomerate and schists of the 


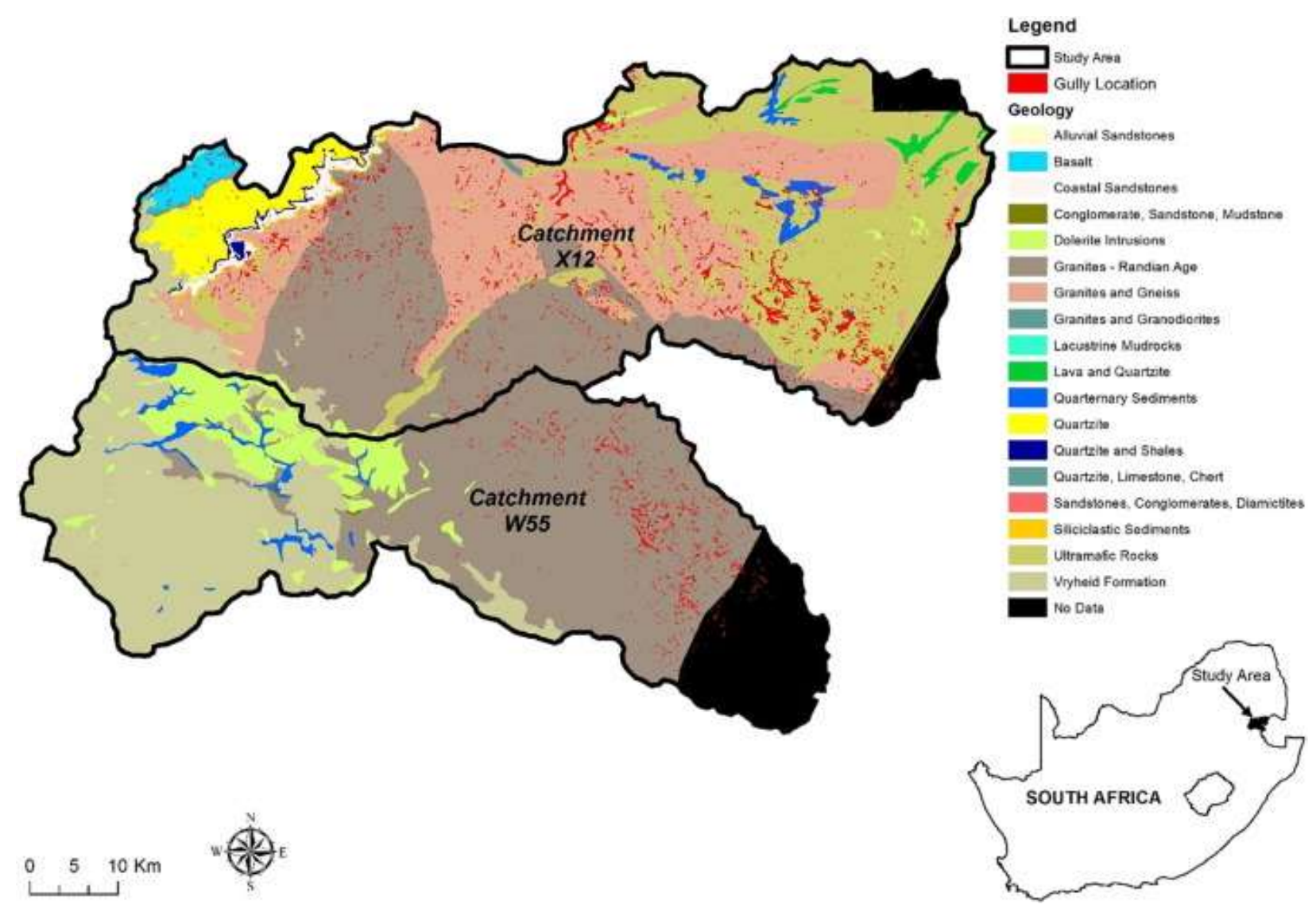

Fig. 1. Location and geological settings of the study area draped with gully areas

Barberton Supergroup (Geological Survey, 1986b). Soils overlying the Randian age granite rocks are mainly characterized by very deep Hutton form (Fig. 2) with varied texture (Fig. 3), whereas the Barberton Supergroup is overlain by erodible duplex soils such as Estcourt and Swartland forms with loamy texture. Soils formed from the shale, sandstone and coal beds of the Vryheid formation are medium deep Hutton, Avalon, Clovelly and Glencoe soil forms association with sandy loam texture (Van den Berg, 2000). 


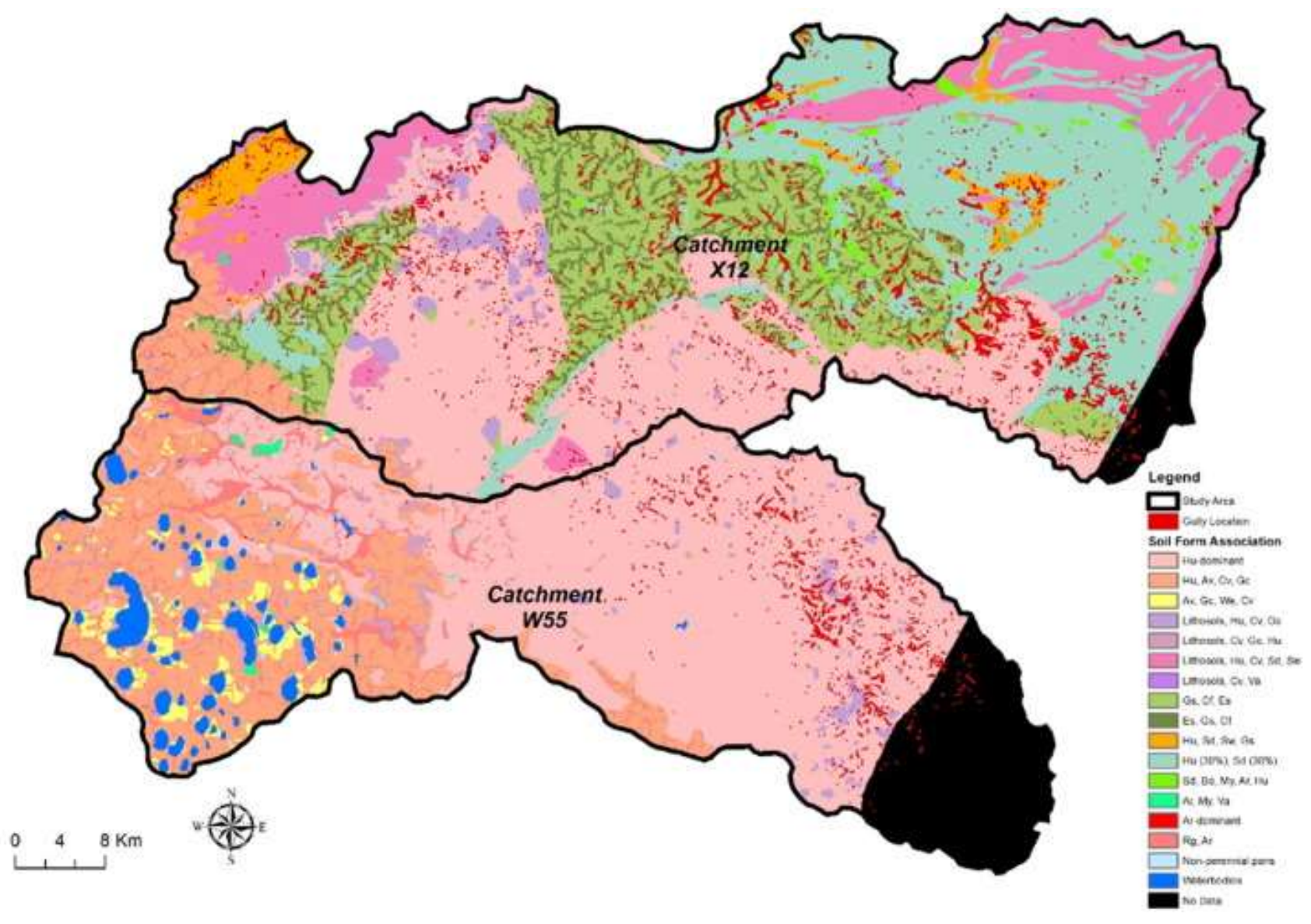

Fig. 2. Soil form association and gully location maps of the study area (Hu: Hutton, Av: Avalon, Cv: Clovelly, Gc: Glencoe, We: Westleigh, Sd: Shortlands, Sw: Swartland, Va: Valsrivier, Gs: Glenrosa, Cf: Cartref, Es: Estcourt, Bo: Bonheim, My: Mayo, Ar: Arcadia and Rg: Rensburg). 


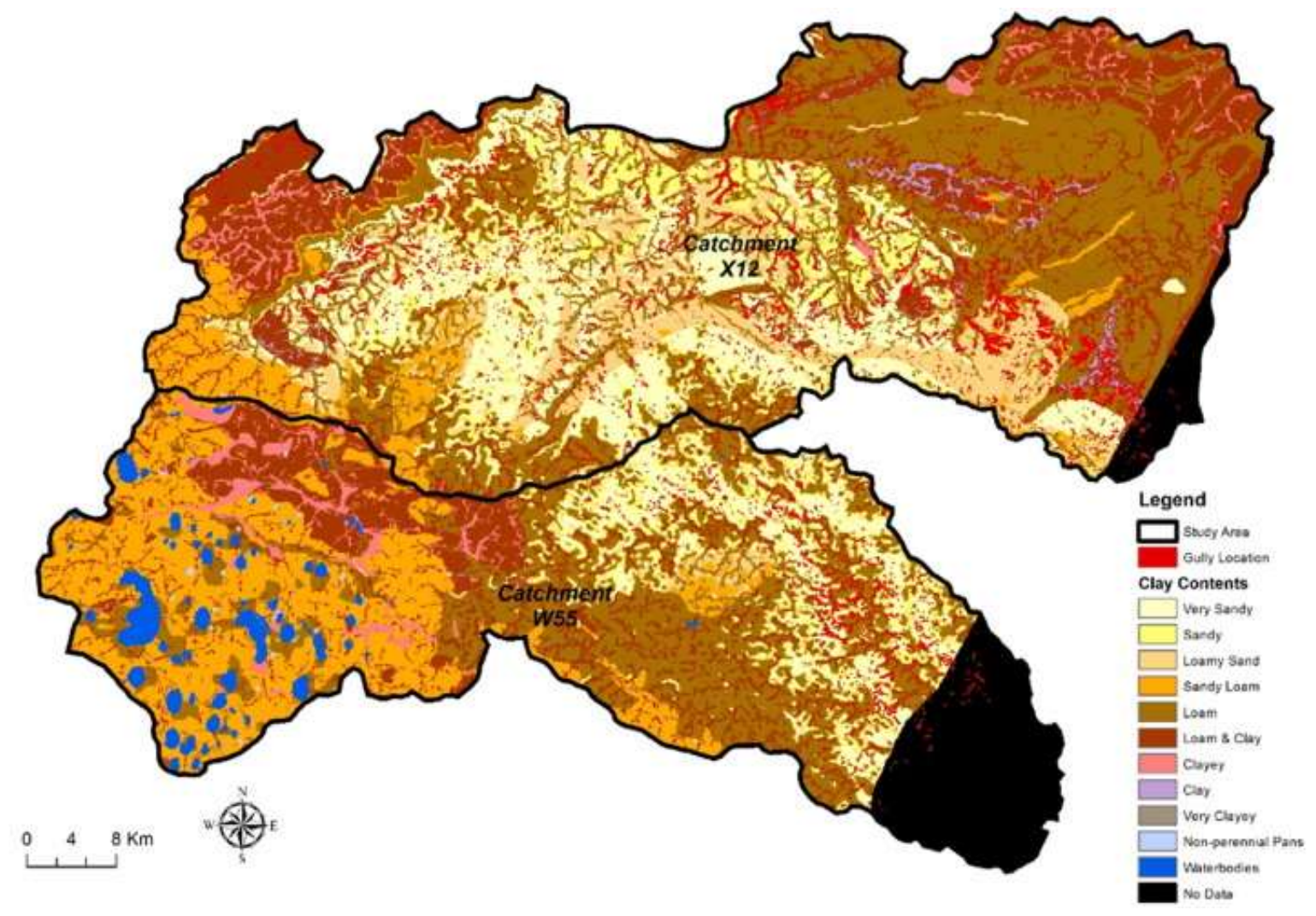

Fig. 3. Soil texture (clay content) and gully location maps of the study area.

Rain mainly falls in the summer months (October to March) and long-term annual averages vary spatially from 600 to $1200 \mathrm{~mm}$. Elevation ranges from 600 to $2400 \mathrm{~m}$ above sea level. The Highveld region in catchment W55 is dominated by grassland whereas Lowveld region of catchment X12 consists of bushveld. The tenure consists of communal land use system in the former KaNgwane homeland east of the study area and the private ownership west of the study area. Subsistence farming dominates the communal area while commercial utilization which includes forest plantations and mining characterize the privately owned land. 


\section{Materials and methods}

Existing spatial datasets were accessed with permission from the Department of Agriculture, Rural Development, Land and Environmental Affairs (DARDLEA). Their original sources are acknowledged below.

\subsection{Contributing factors data}

Geology data were digitized from parts of the 1:250 000 lithostratigraphic sheet maps 2530 Barberton and 2630 Mbabane (Geological Survey, 1986b, Geological Survey, 1986a). The soil datasets were derived by Van den Berg (2000) for DARDLEA using the 12199 landtype soil survey (depth, clay content, and form) observation sites which span eight landtype series maps, namely, 2530 Barberton, 2630 Mbabane, 2428 Nylstroom, 2430 Pilgrim’s Rest, 2528 Pretoria, 2628 Eastrand, 2728 Frankfort and 2730 Vryheid. The soil observation was correlated with 1:250 000 geology map, soil color (derived from bare soil color visible on Landsat TM imagery), terrain unit, altitude, slope and rainfall datasets to produce the soil form association (Fig. 2), clay content (Fig. 3) and soil depth (Fig. 4) maps. 


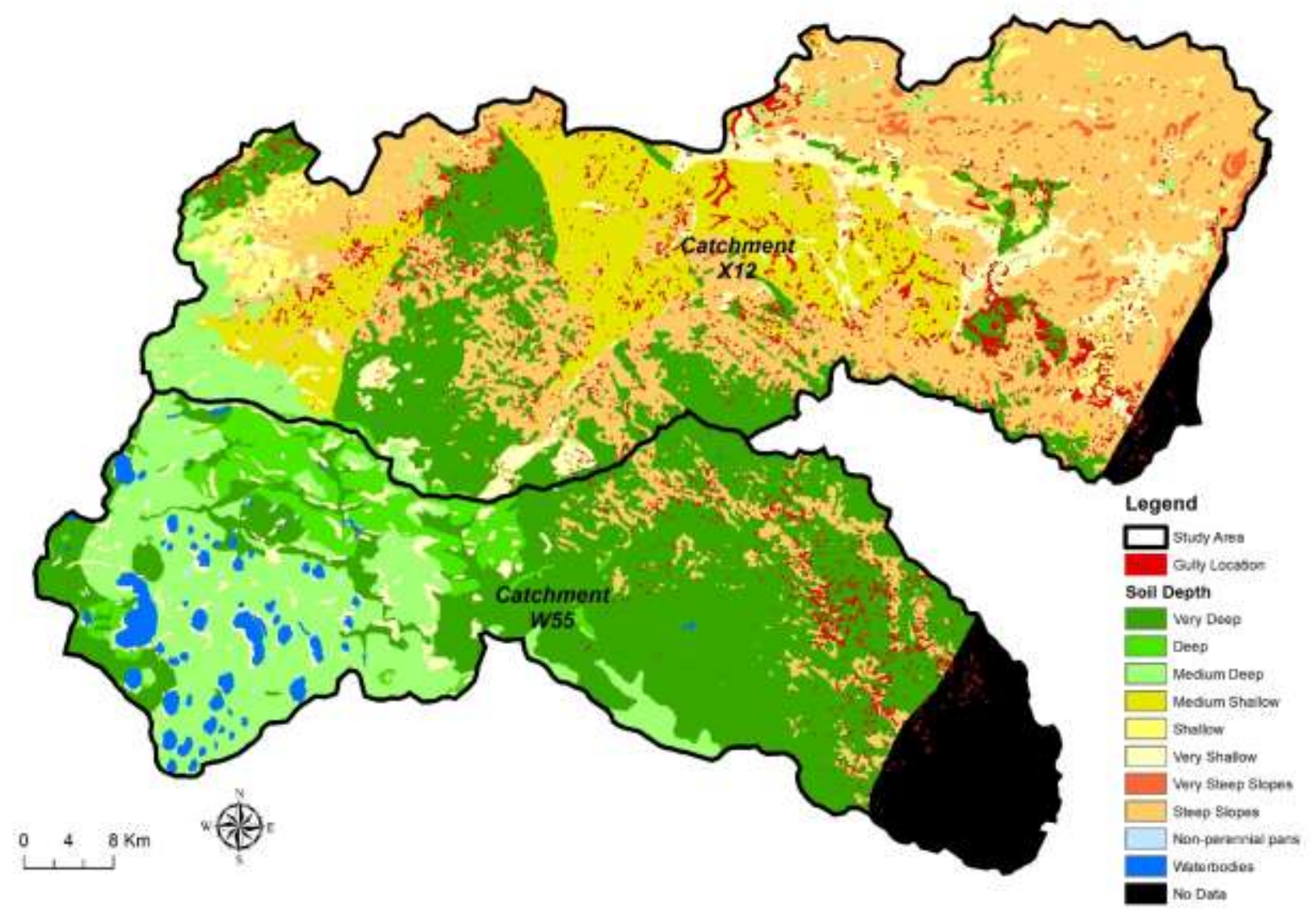

Fig. 4. Soil depth and gully location maps of the study area

Rainfall erosivity data were mapped by Le Roux et al. (2008) using a Revised Universal Soil Loss Equation (RUSLE) model improved by Yu and Rosewell (1996) for Australian conditions. Yu and Rosewell's model considers rainfall seasonality of the region and time of the year to estimate erosive potential. Vegetation data utilized here are the smallest mapping units of the vegetation mapping project of SA, Lesotho and Swaziland coordinated by the South African National Biodiversity Institute (SANBI) (Mucina and Rutherford, 2006). A long-term annual average Normalized Difference Vegetation Index (NDVI) map calculated by the Agricultural Research Council - Institute for Soil, Climate and Water (ARC-ISCW) for the period 1985 to 2003 from the National Oceanic and Atmospheric Administration - Advanced Very High 
Resolution Radiometer (NOAA - AVHRR) satellite imagery (see Wessels et al., 2004) was used as an indicator of vegetation cover. A land cover database derived from the Landsat TM imagery with a grid cell resolution of $30 \mathrm{~m}$ (National Land Cover, 2000) was used, with the improvement on certain classes based on existing higher accuracy data. The cultivated land class was replaced by the digitized field crop boundaries (Fourie, 2009) and the degraded erosion class was replaced by a digitized gully location map (Mararakanye and Le Roux, 2012). Fig. 5 shows the final land cover or land use map.

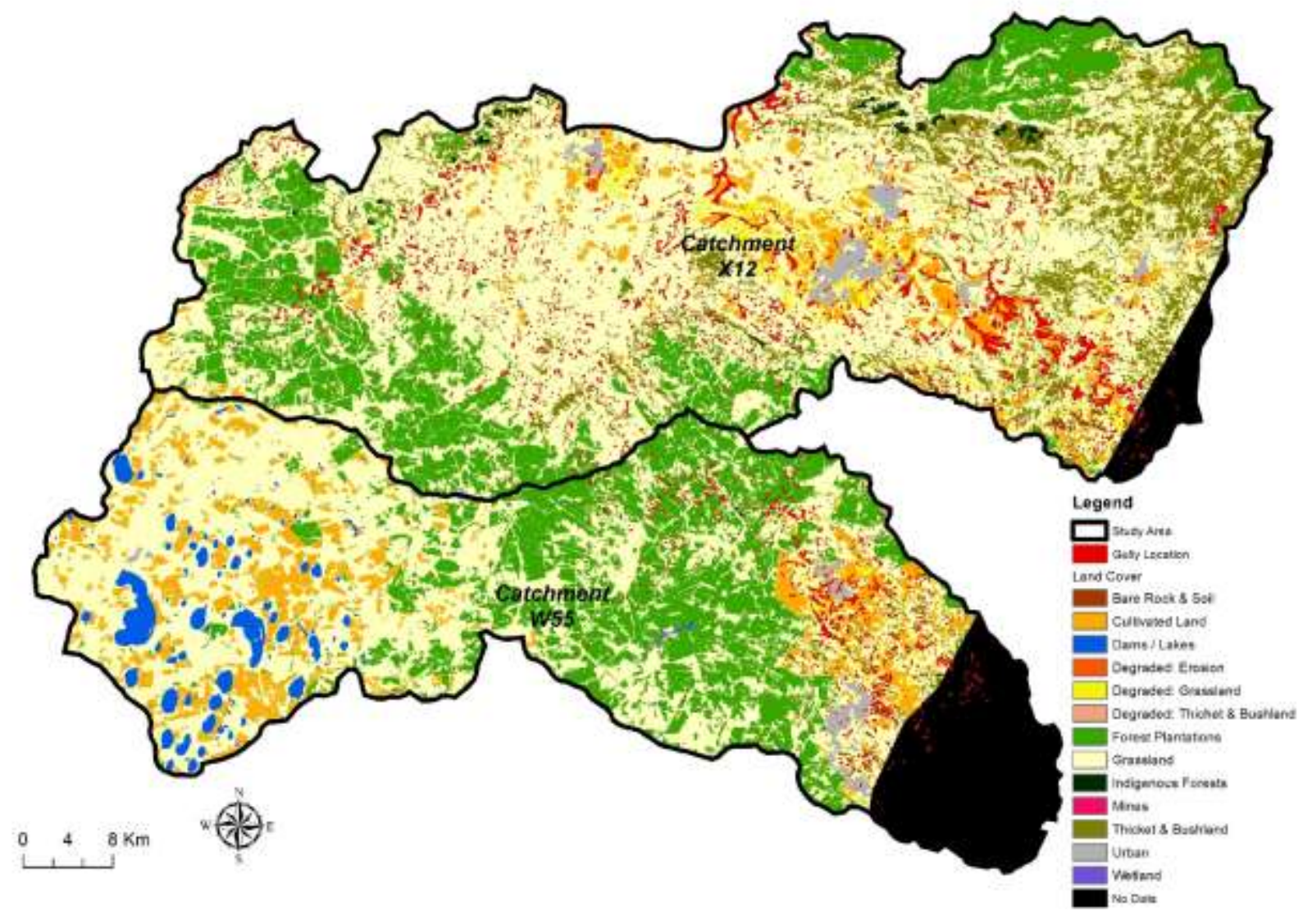

Fig. 5. Land cover and gully location maps of the study area

Topographic variables were extracted from a 10 m cell size Digital Elevation Model (DEM) obtained by means of interpolation of $5 \mathrm{~m}$ interval contours using the Australian National 
University Digital Elevation Model (ANUDEM) algorithm available in the ArcGIS® spatial analyst extension (see Van Niekerk, 2012). The contours were digitized by the Chief Directorate: National Geospatial Information (CD: NGI) of the Department of Rural Development and Land Reform (DRDLR) from the 1:10 000 orthophoto map series and spot heights (Vorster, 2003). The extraction of slope gradient (Fig. 6) and upslope contributing area were based on the implementation of a multi flow directional (MFD) D-Infinity algorithm (Tarboton, 1997) available in the Terrain Analysis Using Digital Elevation Models (TauDEM) tool developed as an add-on extension for Hydrologic Terrain Analysis in ArcGIS® 10 by the Utah State University (USU) (Tarboton and Mohammed, 2013). The D-Infinity algorithm is based on the calculation of flow direction, defined as steepest downwards slope on the eight triangular facets centered at each grid point (Tarboton, 1997). For the calculation of planform curvature, the algorithm of Zevenbergen and Thorne (1987) implemented directly from ArcGIS® spatial analyst tool was used. Planform curvature is calculated on a cell by cell basis using a $3 \times 3$ window. The Topographic Wetness Index $(T W I)$ and Stream Power Index (SPI) were calculated from ArcGIS ${ }^{\circ}$ as a function of slope gradient and upslope contributing area (see Wilson and Gallant, 2000). 


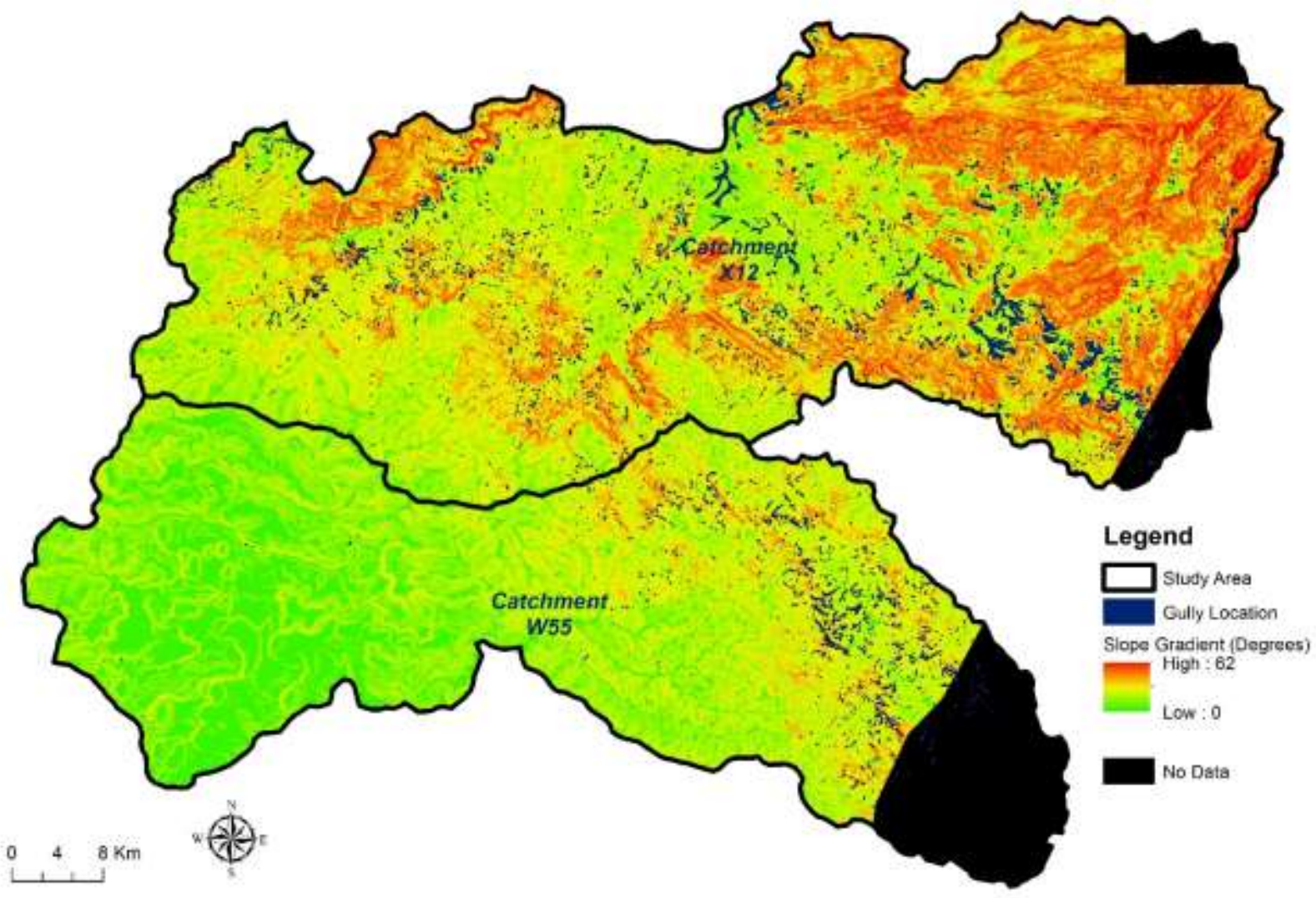

Fig. 6. Slope degrees and gully location maps of the study area

\subsection{Gully mapping}

Gully mapping was based on visual interpretation and analysis of $0.5 \mathrm{~m}$ spatial resolution aerial photographs in the ESRI ${ }^{\circledR} \operatorname{ArcMap}^{\mathrm{TM}}$ software at a scale of 1:1000, that allowed gullies as small as $1 \mathrm{~m}$ width and length to be detected (see Tobler, 1988). The orthorectified aerial photographs utilized were produced in 2009 and 2010 by the CD: NGI of the DRDLR and were acquired using a 4-band multispectral Intergraph Digital Mapping Camera (DMC) with the capability of capturing panchromatic (grayscale), true color (RGB) and color infrared (CIR) images in a single flight (Duncan and Smit, 2013). Gullies were identified mainly as linear erosion features characterized by actively eroding steep sloping and poorly vegetated banks with 
incised channels large enough to be visually detectable by a computer using high spatial resolution $(0.5 \mathrm{~m})$ aerial photographs. The mechanisms behind gully erosion development such as subsurface erosion, rill expansion, overland flow and gully head retreat were outside the scope of the mapping process. An alternative mapping process such as the automated feature extraction approach was not considered since it has been previously shown that the spectral complexity of gullies remain a challenge especially over a large area (Mararakanye and Nethengwe, 2012). Although manual digitizing is time consuming and labor intensive, it was preferred over the automated approach in order to ensure a high level of data accuracy.

\subsection{Assessment of the contributing factors}

The approach adopted for the assessment and quantification of dominant contributing factors includes the use of a GIS and InfVal bivariate statistics. The approach is similar to that employed by Le Roux and Sumner (2012) where each contributing factor was correlated with the gully distribution map using zonal statistics in ArcGIS® Spatial Analyst. This generated figures representing the proportion of gullied area in relation to the size of the respective contributing factor class, required for the InfVal statistical analysis. Subsequently, weighting values based on gully densities were calculated for each factor class. InfVal defines a weight value as the natural logarithm of the gully density for a class divided by the density over the entire study area (Conforti et al., 2011):

$$
W_{i}=\ln \frac{\text { DensClass }}{\text { DensMap }}=\ln \frac{N p_{i} x S_{i} / N p_{i} x N_{i}}{\sum N p_{i} x S_{i} / \sum N p_{i} x N_{i}}
$$


where $W_{i}$ is the weight of class $i$; DensClass is the density of gullies in class $i$; DensMap is the density of gullies in the whole catchment; $N p_{i} x S_{i}$ is the number of pixels that contain gullies in class $i ; N p_{i} x N_{i}$ is the number of pixels within class $i ; \Sigma N p_{i} x S_{i}$ is the total number of pixels that contain gullies in the whole catchment; and $\Sigma N p_{i} x N_{i}$ is the total number of pixels of the whole catchment. A positive value of InfVal weight implies a strong or significant influence of a particular class on gully, whereas a negative value indicates a weak influence of a class on gully (Conforti et al., 2011; Luca et al., 2011).

\section{Results}

\subsection{Gully location map}

The spatial distribution of gully erosion features in catchments X12 and W55 is depicted in Fig. 7. Gullies of different sizes in catchment X12 are prominent throughout the study area, affecting approximately $0.6 \%$ of the area whilst in catchment $\mathrm{W} 55$, they mainly predominate along the eastern border, affecting $0.2 \%$ of the total catchment area. Gully erosion features mapped include both the active and stabilized gully systems. Active gullies are mainly characterized by bare soil with no or little vegetation (Fig. 8) and contribute to large sediment yields in the Komati and Usutu River catchments. Stabilized gullies have active banks and the floor is overgrown with vegetation (Fig. 9). Compared to the map of Mararakanye and Le Roux (2012) (their Fig. 2), there is an increase in the number of gullies detected. A large number of smaller discontinuous gullies are evident across the whole study area, which could not be mapped previously by Mararakanye and Le Roux (2012) due to the limitation of a $10 \mathrm{~m}$ spatial resolution SPOT 5 imagery compared to $0.5 \mathrm{~m}$ of aerial photographs utilized here. Detection of 
smaller discontinuous gullies becomes a challenge when the feature is less than or equal to the spatial resolution of the imagery. The $0.5 \mathrm{~m}$ spatial resolution of the aerial photographs enables the detection of gully erosion features as small as $1 \mathrm{~m}$, compared to a minimum of $10 \mathrm{~m}$ detectable using merged bands of SPOT 5 imageries at $5 \mathrm{~m}$ spatial resolution (Tobler, 1988) previously utilized by Mararakanye and Le Roux (2012).

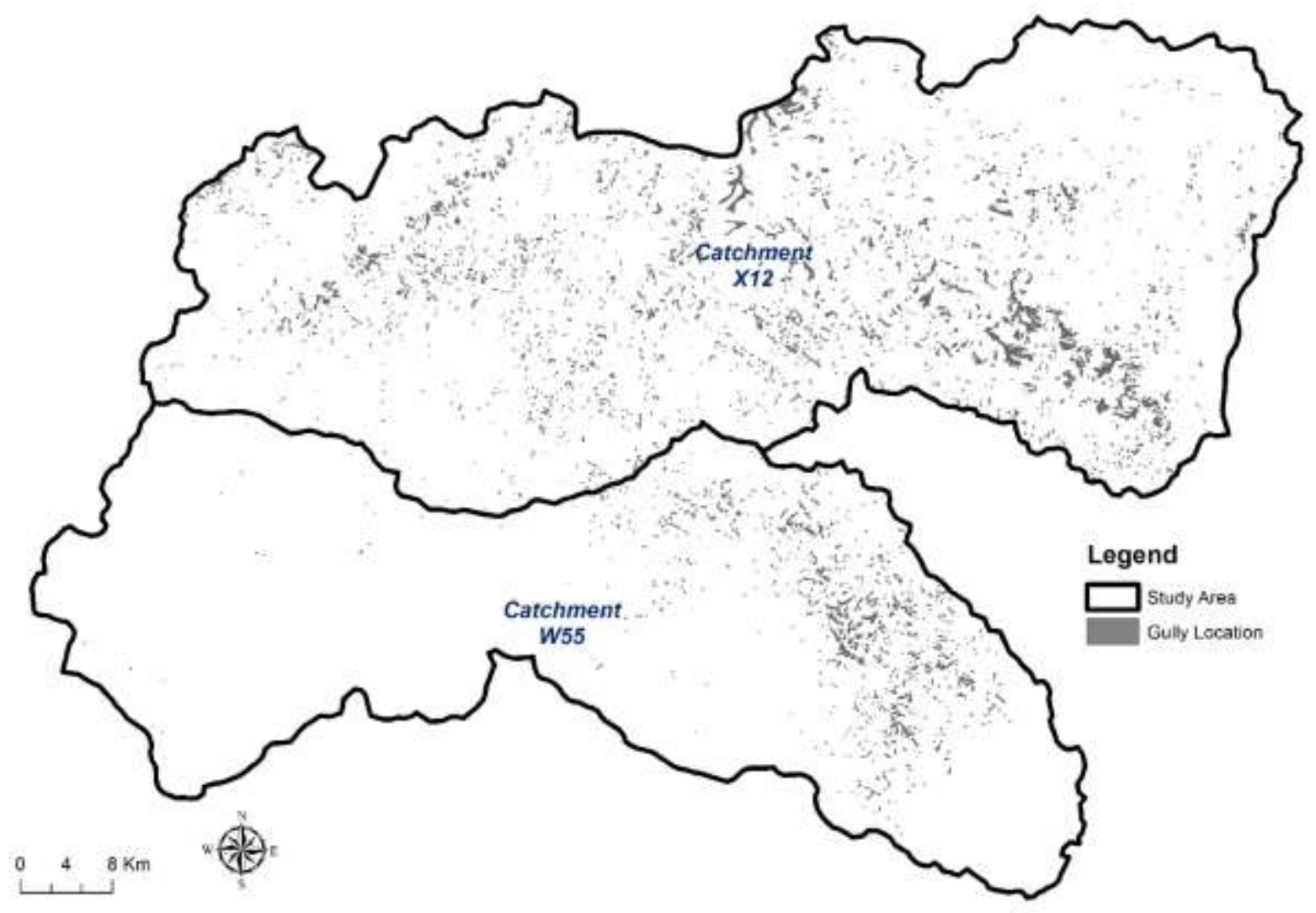

Fig. 7. Location of gullies in catchments X12 and W55. 


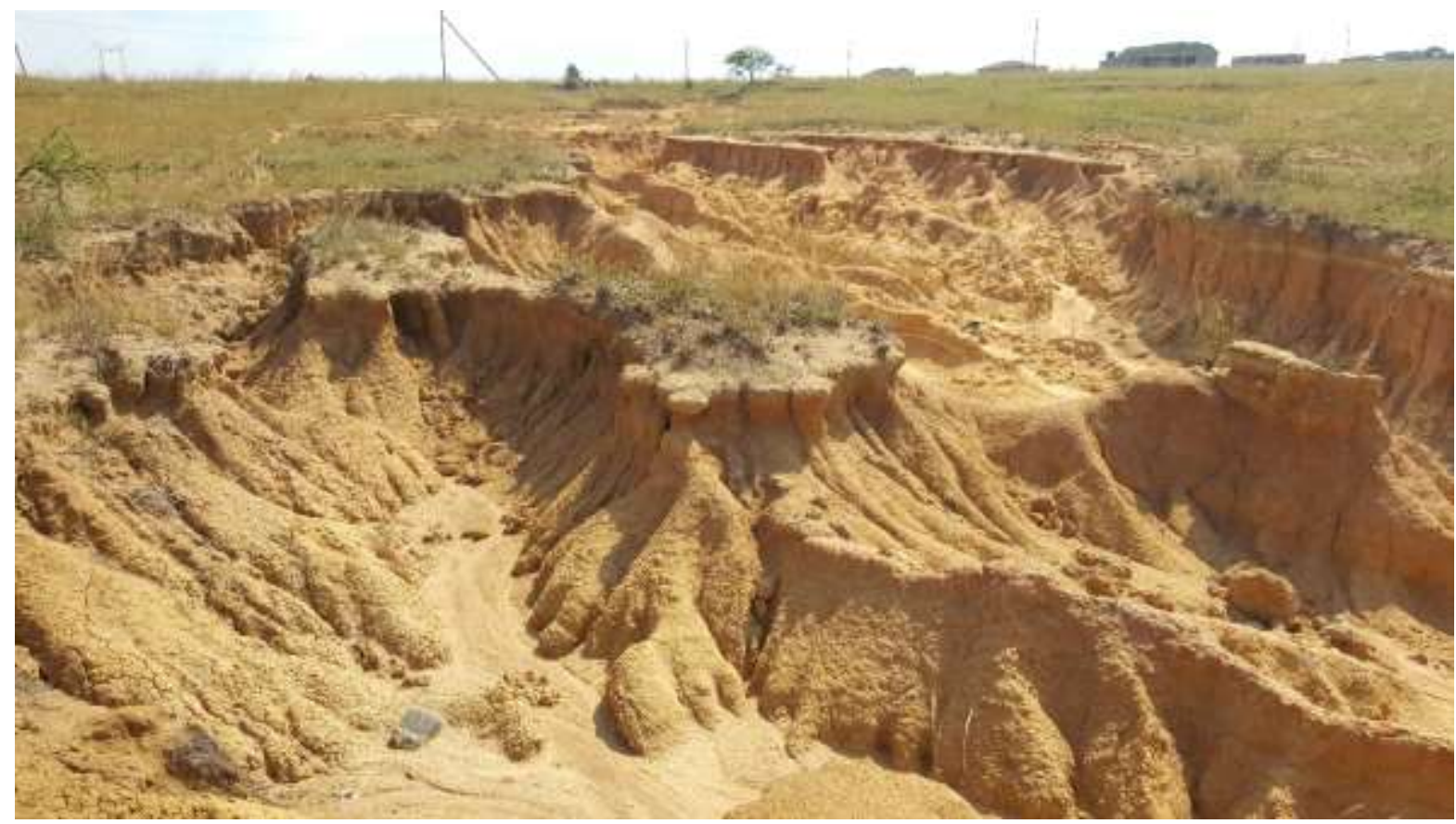

Fig. 8. An example of active gully on a grazing land near Elukwatini in catchment X12

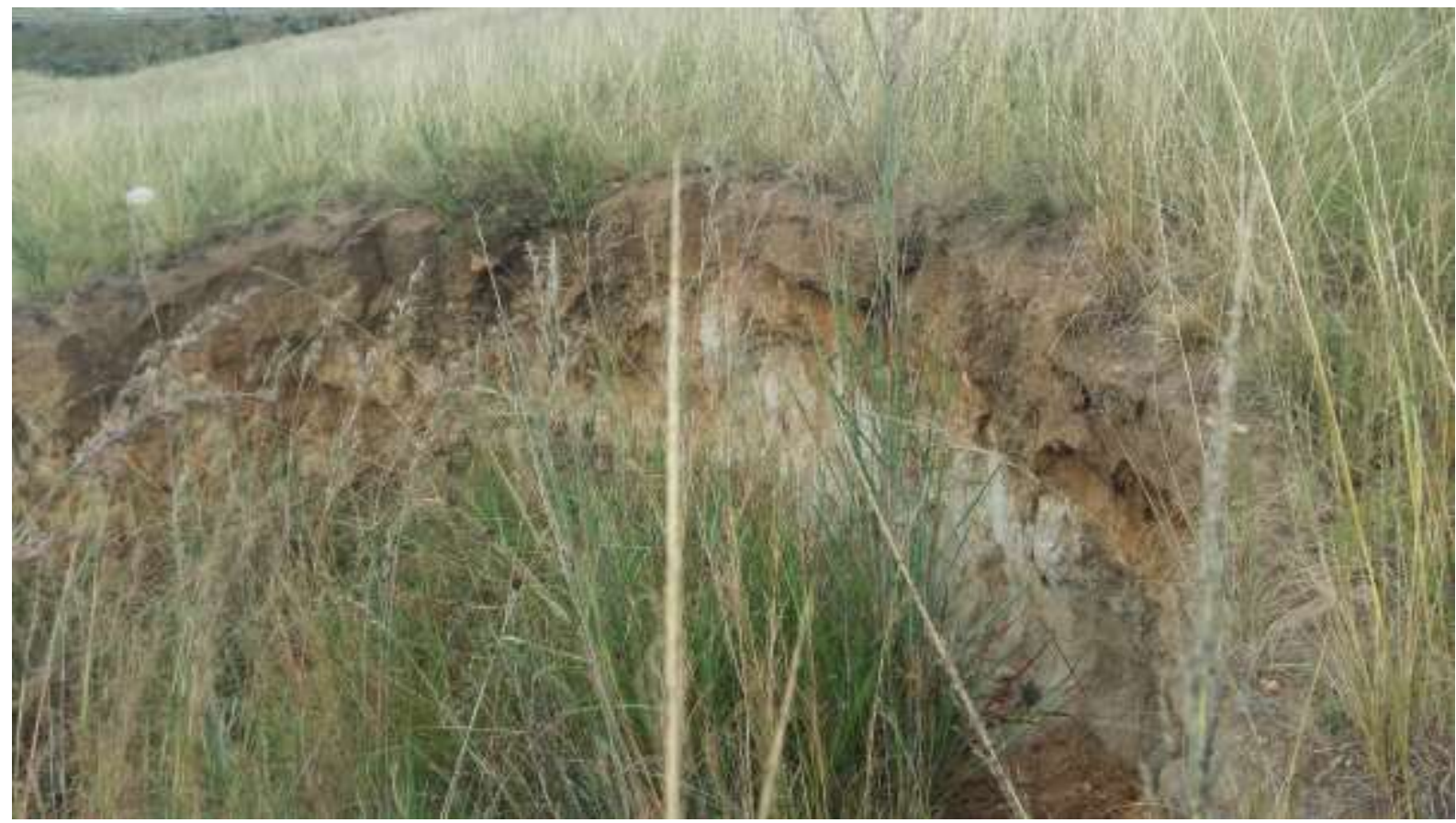

Fig. 9. An example of stabilized gully overgrown with vegetation on its floor and active banks near Empuluzi in catchment W55 


\subsection{Influence of various factors on gully erosion}

The influence of contributing factors is presented in a series of tables (Tables 1-4) showing the density of gullies in a class and the weight of a class for selected examples of gully erosion factors with influence on gullies.

\subsubsection{Influence of soil and geology}

The intensity of influence of various soils and geology classes on gully erosion in each catchment is evaluated using $W_{i}$ presented in Table 1, which also includes gully density per class (DensClass). Gullies in catchment W55 are influenced by oxidic soils comprising of Hutton and Clovelly forms as well as Lithosols and Plinthic (Glencoe form) soil groups. On landscape areas where Hutton soils are dominant, they are usually very deep $(\geq 120 \mathrm{~cm})$ and have texture varying from loamy sand, sandy, very sandy, loam and loam/clay. However, loam and loam/clay classes have weak influence (negative $W_{i}$ ) on gully erosion in catchment W55. Lithosols and plinthic soil occur along the steep areas where rock outcrops and soil texture classes consist mainly of loamy sand, sandy and very sandy. Both oxidic, lithosols and plinthic soils are underlain by intrusive granitic rocks of the Randian age.

In catchment X12, oxidic (Hutton and Shortlands soil forms), duplex (Estcourt soil form) and lithic (Glenrosa and Cartref soil forms) occur frequently and are highly influential on the development of gullies. Duplex and lithic soils occur on weakly weathered granite and gneiss rocks of the Swazian age with shallow saprolites at the valley floor. Very shallow oxidic soils with clay and loam texture overlie ultramafic rocks whilst Quaternary unconsolidated sediments underlie very deep loam and clay texture soil. The very shallow clay belonging to Hutton and Shortlands soil forms has the highest influence on gullies. 
Table 1. Comparison of InfVal $W_{i}$ for soil and geology.

\begin{tabular}{|c|c|c|c|c|}
\hline \multirow[t]{2}{*}{ Contributing Factor Classes } & \multicolumn{2}{|c|}{ Catchment W55 } & \multicolumn{2}{|c|}{ Catchment X12 } \\
\hline & DensClass & $W_{i}$ & DensClass & $W_{i}$ \\
\hline \multicolumn{5}{|l|}{ Clay Content } \\
\hline Clay & 0 & None & 0.02771 & 1.5 \\
\hline Loam & 0.00052 & -1.2 & 0.00815 & 0.3 \\
\hline Loam Clay & 0.00132 & -0.2 & 0.00568 & -0.1 \\
\hline Loamy Sand & 0.00796 & 1.6 & 0.00536 & -0.1 \\
\hline Sandy & 0.00339 & 0.7 & 0.00441 & -0.3 \\
\hline Very Sandy & 0.00885 & 1.7 & 0.00394 & -0.5 \\
\hline \multicolumn{5}{|l|}{ Soil Depth } \\
\hline Very Deep & 0.00215 & 0.3 & 0.00922 & 0.4 \\
\hline Deep & 0.00001 & -5.1 & 0.02045 & 1.2 \\
\hline Medium Shallow & 0 & None & 0.00919 & 0.4 \\
\hline Shallow & 0 & None & 0.00986 & 0.5 \\
\hline Very Shallow & 0.00018 & -2.2 & 0.01088 & 0.6 \\
\hline Steep Slopes & 0.00827 & 1.6 & 0.00298 & -0.7 \\
\hline \multicolumn{5}{|l|}{ Soil form Association } \\
\hline Estcourt, Glenrosa, Cartref & 0 & None & 0.01768 & 1 \\
\hline Shortlands, Bonheim, Mayo, Arcadia, Hutton & No data & None & 0.01383 & 0.8 \\
\hline Hutton, Shortlands, Swartland, Glenrosa & No data & None & 0.01362 & 0.8 \\
\hline Lithosols, Clovelly, Valsrivier & No data & None & 0.01157 & 0.6 \\
\hline Glenrosa, Cartref, Estcourt & 0 & None & 0.00663 & 0.1 \\
\hline Hutton-dominant & 0.00269 & 0.5 & 0.0058 & -0.1 \\
\hline Lithosols, Hutton, Clovelly, Glencoe & 0.00526 & 1.1 & 0.00358 & -0.6 \\
\hline \multicolumn{5}{|l|}{ Geology } \\
\hline Quaternary unconsolidated sediments & 0.00012 & -2.7 & 0.018 & 1.1 \\
\hline Randian age granite rock & 0.00322 & 0.7 & 0.00256 & -0.9 \\
\hline Swazian age granite and gneiss rocks & No data & None & 0.01321 & 0.8 \\
\hline Ultramafic rock - Hooggenoeg Formation & No data & None & 0.00812 & 0.3 \\
\hline Ultramafic rock - Komati Formation & No data & None & 0.02274 & 1.3 \\
\hline Ultramafic rock - Theespruit Formation & No data & None & 0.0129 & 0.7 \\
\hline Ultramafic rock & No data & None & 0.00715 & 0.1 \\
\hline Ultramafic rock - Sandspruit Formation & No data & None & 0.01549 & 0.9 \\
\hline
\end{tabular}




\subsubsection{Influence of topography}

The role of each individual topographic variable class in the initiation of a gully is evaluated

in Table 2. A significant influence on gully erosion was observed on slope gradients between $4.5^{\circ}$ and $27^{\circ}$ in catchment $\mathrm{W} 55$, more specifically where flow accumulates as reflected by positive InfVal weight of higher upslope contributing area values. An area with slope gradient of less than $4.5^{\circ}$ is less susceptible to the development of gullies in catchment W55. Furthermore, gully development is more probable on concave surfaces on an area where there is high enough stream power to entrain sediments (high $S P I$ ), but a gully can also develop on convex surfaces as shown in Table 2. The influence of TWI shows all classes with the exception of one class (8-10) to be significant in the development of gullies. Catchment W55 results generally contrast with those in catchment X12 since a strong influence on gullies was observed on nearly level land to moderately steep slopes $\leq 13.5^{\circ}$. However, similar to catchment W55, areas which accumulate water flow are susceptible to gully erosion and represent a water convergent zone. A significant influence on gully erosion was also observed on high $T W I$ values which generally correspond well with high upslope contributing area values and represent zones of saturation where there is abundant soil moisture caused by runoff water (Wilson and Gallant, 2000). The influence of SPI in catchment X12 is highly variable as both the area with potential low and high velocities of water flow are important. 
Table 2. Comparison of InfVal $W_{i}$ for topographic variables

\begin{tabular}{|c|c|c|c|c|}
\hline \multirow[t]{2}{*}{ Contributing Factor Classes } & \multicolumn{2}{|c|}{ Catchment W55 } & \multicolumn{2}{|c|}{ Catchment X12 } \\
\hline & DensClass & $W_{i}$ & DensClass & $\overline{W_{i}}$ \\
\hline \multicolumn{5}{|l|}{ Slope Gradient } \\
\hline $0-0.23^{\circ}$ & 0.00025 & -1.9 & 0.02034 & 1.2 \\
\hline $0.23-0.9^{\circ}$ & 0.0004 & -1.4 & 0.01566 & 0.9 \\
\hline $0.9-2.25^{\circ}$ & 0.00074 & -0.8 & 0.01075 & 0.5 \\
\hline $2.25-4.5^{\circ}$ & 0.00143 & -0.2 & 0.00734 & 0.2 \\
\hline $4.5-6.75^{\circ}$ & 0.00324 & 0.7 & 0.00818 & 0.3 \\
\hline $6.75-13.5^{\circ}$ & 0.00633 & 1.3 & 0.00663 & 0.1 \\
\hline$>13.5^{\circ}$ & 0.00304 & 0.6 & 0.00138 & -1.5 \\
\hline \multicolumn{5}{|l|}{ Upslope Contributing Area } \\
\hline 2 to 4 & 0.00092 & -0.6 & 0.00489 & -0.2 \\
\hline 4 to 5 & 0.0012 & -0.3 & 0.00349 & -0.6 \\
\hline 5 to 6 & 0.0013 & -0.2 & 0.00512 & -0.2 \\
\hline 6 to 7 & 0.0018 & 0.1 & 0.01037 & 0.5 \\
\hline$>7$ & 0.00604 & 1.3 & 0.02653 & 1.5 \\
\hline \multicolumn{5}{|l|}{ Planform Curvature } \\
\hline Concave & 0.01072 & 1.9 & 0.01201 & 0.7 \\
\hline Flat & 0.00053 & -1.1 & 0.00522 & -0.2 \\
\hline Convex & 0.00175 & 0.0 & 0.00318 & -0.7 \\
\hline \multicolumn{5}{|c|}{ Topographic Wetness Index (TWI) } \\
\hline 2 to 4 & 0.00219 & 0.3 & 0.00087 & -2.0 \\
\hline 4 to 6 & 0.00245 & 0.4 & 0.00262 & -0.9 \\
\hline 6 to 8 & 0.00186 & 0.1 & 0.00503 & -0.2 \\
\hline 8 to 10 & 0.00116 & -0.4 & 0.00945 & 0.4 \\
\hline $10-26.8$ & 0.00212 & 0.2 & 0.02998 & 1.6 \\
\hline \multicolumn{5}{|l|}{ Stream Power Index (SPI) } \\
\hline$<0$ & 0.0002 & -2.1 & 0.00897 & 0.4 \\
\hline 0 to 2 & 0.00045 & -1.3 & 0.00656 & 0.1 \\
\hline 2 to 4 & 0.00158 & 0.0 & 0.00455 & -0.3 \\
\hline 4 to 6 & 0.0067 & 1.4 & 0.00818 & 0.3 \\
\hline 6 to 8 & 0.02152 & 2.6 & 0.02593 & 1.4 \\
\hline 8 to 14 & 0.01297 & 2.1 & 0.01753 & 1.0 \\
\hline
\end{tabular}

\subsubsection{Influence of vegetation and land use}

The relationship between vegetation and land use is closely related. Land use plays a role in the modification of natural environment and hence land cover percentage (e.g. Gabris et al., 
2003). In this study, natural environments of the low lying areas in catchment X12 have been transformed to urban and arable land with a moderate to high vegetation cover percentage amid the Swaziland Sour Bushveld (SSB) and the fragmented patches of the Barberton Serpentine Sourveld (BSS). The cultivated land bounded by the SSB with moderate and moderate to high vegetation cover percentage has a significant influence on gully erosion (Table 3). The strong influence on gully erosion was also observed on the BSS which is marginally grazed and cultivated. Indigenous vegetation in catchment W55 has been replaced mainly by tree plantations, urban and arable land, but these do not have a significant impact on gullies. A significant influence on gully erosion of Kangwane Montane Grassland (KMG) was observed in catchment W55. Gullies in the KMG vegetation type are more prominent on degraded grassland, bare rock \& soil, thicket \& bushland and indigenous forest than on cultivated commercial land. The associated vegetation cover percentage is classified as moderate and moderate to high.

Table 3. Comparison of InfVal $W_{i}$ for vegetation and land use.

\begin{tabular}{lcccc}
\hline Contributing Factor Classes & \multicolumn{2}{c}{ Catchment W55 } & \multicolumn{2}{c}{ Catchment X12 } \\
\hline & DensClass & $\boldsymbol{W}_{\boldsymbol{i}}$ & DensClass & $\boldsymbol{W}_{\boldsymbol{i}}$ \\
\cline { 2 - 5 } Vegetation Types & & & & \\
KaNgwane Montane Grassland & 0.00317 & 0.6 & 0.00488 & -0.2 \\
Swaziland Sour Bushveld & No data & None & 0.01238 & 0.7 \\
Barberton Serpentine Sourveld & No data & None & 0.01911 & 1.1 \\
Normalized Difference Vegetation Index & & & & \\
Moderate & 0.00329 & 0.7 & 0.01089 & 0.6 \\
Moderate to High & 0.00162 & 0.0 & 0.00711 & 0.1 \\
Land Cover/ Land Use & & & & \\
Indigenous Forests & 0.00208 & 0.2 & 0.00004 & -5 \\
Thicket \& Bushland & 0.00285 & 0.5 & 0.00125 & -1.6 \\
Bare Rock \& Soil & 0.00501 & 1.1 & 0.00162 & -1.3 \\
Degraded: Grassland & 0.0092 & 1.7 & 0.00585 & -0.1 \\
Cultivated Land & 0.00137 & -0.2 & 0.00788 & 0.2 \\
Degraded: Erosion & 0.4431 & 5.6 & 0.28262 & 3.8 \\
\hline
\end{tabular}




\subsubsection{Influence of rainfall erosivity}

Rainfall is the driving force for water erosion related processes, including the formation of gullies (Vanwalleghem et al., 2005), and erosivity varies according to the quantity, frequency and intensity of rainfall (Thiemann et al., 2005). In Table 4, the influence of rainfall erosivity derived from Le Roux et al. (2008) on gullies is shown. Areas in catchment W55 with relatively higher rainfall erosivity values have a significant influence on gully occurrence. In catchment $\mathrm{X} 12$, however, the influence of rainfall erosivity is not clear since higher erosivity values coincide with negative values of InfVal $W_{i}$. Areas with higher rainfall erosivity in catchment X12 occur along the mountain ranges, east of the catchment where the slopes are steep to very steep. As indicated earlier, steep areas in catchment X12 are not susceptible to gully erosion.

Table 4. Comparison of InfVal $W_{i}$ for rainfall erosivity classes.

\begin{tabular}{lcccc}
\hline Contributing Factor Classes & \multicolumn{2}{c}{ Catchment W55 } & \multicolumn{2}{c}{ Catchment X12 } \\
\hline & DensClass & $\boldsymbol{W}_{\boldsymbol{i}}$ & DensClass & $\boldsymbol{W}_{\boldsymbol{i}}$ \\
\cline { 2 - 5 } Rainfall Erosivity & & & & \\
2922 to 3000 & No data & None & 0.01136 & 0.6 \\
3000 to 3500 & 0.0002 & -2.1 & 0.00792 & 0.2 \\
3500 to 4000 & 0.00294 & 0.6 & 0.00697 & 0.1 \\
4000 to 4500 & 0.00362 & 0.8 & 0.00658 & 0.1 \\
4500 to 5000 & No data & None & 0.00314 & -0.7 \\
5000 to 5500 & No data & None & 0.00092 & -1.9 \\
5500 to 6000 & No data & None & 0.00131 & -1.6 \\
\hline
\end{tabular}

\section{Discussion}

Gullies occur in a wide range of soils and geology, and for catchment W55, they are confined to granite rocks of the Randian age and its associated soil characteristics other than loam and loam clay textured soils. Soils overlying these granite rocks can be grouped into oxidic (Hutton and Clovelly forms), plinthic (Glencoe form) and lithosols; however, the oxidic Hutton form 
dominate. As a result, the soil depth in the whole granite rocks area reflect that of an oxidic Hutton form which is very deep. The texture varies from very sandy to loam and loam clay on thick layer of saprolite beneath the red and yellow apedal B horizons associated with deep weathering (Soil Classification Working Group, 1991). Oxidic soils are generally stable against disaggregation and dispersion and hence erosion due to the presence of free iron oxides associated with highly weathered rocks (see Laker, 2004). However, the sandy texture makes them vulnerable to gully erosion since the very sandy class has the highest InfVal $W_{i}$. Soils with sandy texture have the collapsible grain structure and given the role of other factors such as land use/cover, gully erosion susceptibility may be high. Natural grassland in this granite rocks area is degraded because of livestock grazing in the communal land compared to a large area of commercial plantation, natural grassland and thicket \& bushland which provide better soil protection in catchment X12 where granite rocks area with similar soil characteristics underlie a significant portion of the landscape. It is highly likely that the susceptibility to gully erosion of the materials developed from the Randian age granite rocks in catchment W55 is influenced by overgrazing and sandy texture of the Hutton soil form.

The susceptibility of the Swazian age granite and gneiss rocks in catchment X12 may be directly linked to the soil developed thereof which belongs to the lithic group represented by Glenrosa and Cartref forms and duplex soil pattern comprising of medium shallow and loam textured Estcourt form. Lithic soils have a thin layer of saprolite beneath the surface horizon which is an indicative of limited rock weathering (Fey, 2009) and characterize steep slopes and convex crests with medium shallow very sandy to loamy sand soils. However, steep slopes and convex crests are not susceptible to the development of gullies in catchment X12 (Table 2). Duplex soils observed have a strong blocky, prismatic or columnar structure and cutanic 
character in the B horizon and a marked increase in clay compared to the overlying horizon from which it is separated by a clear or abrupt transition boundary (Fey, 2009). The surface horizon is usually dispersive and prone to crusting which makes duplex soils prone to gullying through tunneling (e.g. Rienks et al., 2000; Laker, 2004; Le Roux and Sumner; 2012). Duplex soils developed from granite rock exhibit high sodium especially in low lying areas and where rainfall is such that seepage water has high Sodium Absorption Ratio (SAR) (Elges, 1985). Sodium is the most dispersive cation in soils which influence the erodibility (Laker, 2004). Additionally, duplex soil is found on lower landscape positions characterized by flow convergence and accumulation which is a favorable position for gully occurrence (Table 2). The erodibility of duplex soils in catchment X12 is also enhanced by the anthropogenic activities, since the majority of the Swazian age granite and gneiss rocks area is cultivated and natural vegetation is disturbed.

The most distinguishing erodibility factor between the two catchments is the ultramafic rocks which occur in catchment X12. Overlying these rocks are loam and clay textured oxidic soil patterns comprising Hutton, Shortlands and Clovelly forms with patches of lithosols and duplex Swartland form along the steep slopes as well as melanic (Bonheim and Mayo forms) and vertic (Arcadia form) soil groups. Soil depth varies from very shallow to medium shallow and in addition, large area is mapped as steep slopes due to the lack of data (see Van den Berg, 2000), but Le Roux et al. (2006) found that steep areas are normally characterized by erodible shallow soils. The characteristics of the oxidic soils observed here differ with those underlain by the Randian age granitic rocks in that their depth is shallow to medium shallow but their influence on erodibility is both high. Ultramafic rock is the common parent material for vertic soils in SA which are identified by cracking and swelling associated with high smectite minerals (Bühmann 
and Schoeman, 1995). Thus, the occurrence of vertic Arcadia soil form is not surprising and promote gullying when water passes through the cracks and saturates the subsoil horizon thereby moving soil particles laterally as seepage causing subsurface channels (Beckedahl, 1977). The susceptibility to gully erosion of the materials developed from ultramafic rocks is high, typically where the soil is disturbed by cultivation. However, where there is better cover provided for by natural grassland and thicket \& bushland, the proportion of gullies is low.

Both catchments are underlain by slight proportions of the Quaternary unconsolidated sediments with different susceptibility to gully erosion. High influence on gully erosion was observed on Quaternary unconsolidated sediments in catchment X12. In these sediments, three major soil patterns of the dominant soil form association class include the oxidic (Hutton and Shortlands forms), duplex (Swartland form) and lithic (Glenrosa form) soil groups characterized by very deep soil with loam and clay texture. The most dominant oxidic soil group is characterized by iron (Fe) oxides accumulated during weathering which contributes to the stability of soil against erosion. According to Laker (2004), free iron oxide is one of the factors that determine the stability of soil against disaggregation and dispersion. The occurrence of duplex Swartland soil form may have had a bigger role to play in the susceptibility of the Quaternary unconsolidated sediments material to gully erosion since it is well documented that duplex soils are dispersive and easily lose aggregation (e.g. Rienks et al., 2000; Laker, 2004; Le Roux and Sumner; 2012). Land use/cover of the area underlain by Quaternary unconsolidated sediments in catchment X12 is mainly natural grassland, thicket \& bushland and cultivation in patches.

Soils developed from Quaternary unconsolidated sediments in catchment W55 belongs to vertic group comprising of very deep Rensburg and Arcadia forms with clayey texture. Although 
these soils are generally regarded as highly erodible due to the cracking and swelling associated with high smectite minerals (Bühmann and Schoeman, 1995; Fey, 2009), they are less susceptible to gully erosion in catchment W55 due to the role of other factors. Cultivation and livestock grazing are the dominant land uses in this area but the land appear to be well managed under the private ownership compared to the communal land further afield of the catchment where overgrazing and cultivation without implementing proper conservation measures is blamed for widespread gullying.

Within all the mentioned geological settings and soils, gullies were observed along natural drainage lines marked by positive InfVal weights on high upslope contributing area. These are areas where flow accumulates and may include manmade linear elements such as drill lines, plough furrows and parcel borders as observed elsewhere (see Stocking and Murnaghan, 2000; Vanwalleghem et al., 2005; Hancock and Evans, 2006). In any given area, the topography of a landscape is such that water accumulates in one or more natural or manmade waterways before reaching the main stream or river channel. Waterways represent a convergence zone where planform curvature is concave which influence gullies because they cause the upslope contributing areas to increase downslope, thereby generating greater runoff (Mathis, 2007). Other topographic variables such as $T W I$ and SPI are closely related to the upslope contributing area as shown in Fig. 10 where both high values are associated with gully erosion. A high $T W I$ value is associated with significant influence on gullies in catchment X12 due to high soil moisture accumulation and inability of soil to hold together. In catchment W55, both areas with low and high soil moisture are significantly affected by gullies. Areas with high SPI in catchment W55 influence gully formation due to high potential energy available to entrain sediments 
(Kakembo et al., 2009), but in catchment X12, even the area with low potential energy is associated with gullies.

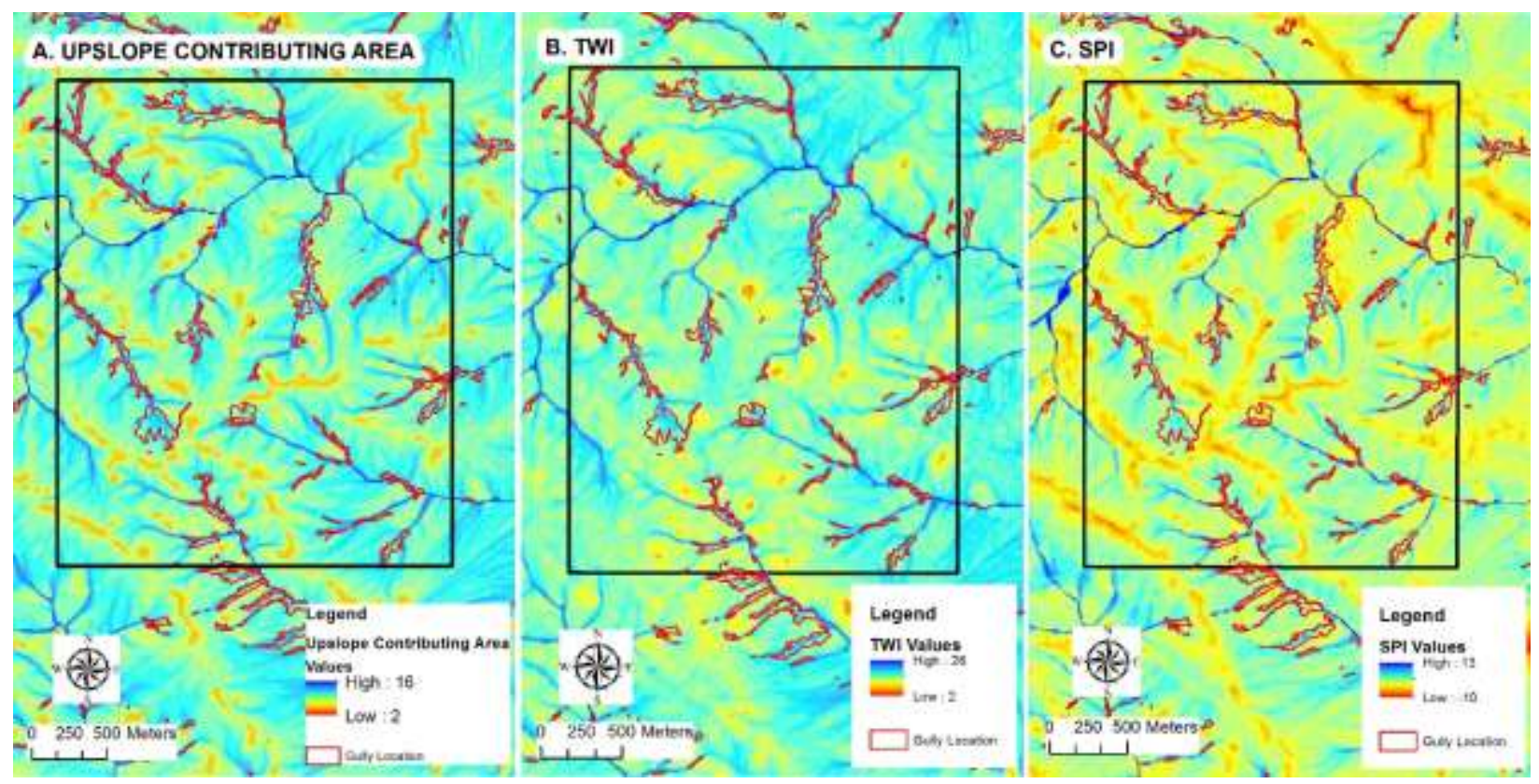

Fig. 10. An example of the relationship between the spatial distribution of (A) upslope contributing area, (B) TWI and (C) SPI in catchment W55

The influence of slope gradient varies between the two catchments. Steeper slopes have a greater influence on gully location in catchment W55 compared to gentler slopes in catchment X12. The majority of studies in SA regard gentler slope gradients as most susceptible to gully erosion (e.g. Laker, 2004; Vetter, 2007; Kakembo et al., 2009; Le Roux and Sumner 2012; Manjoro et al., 2012) due to an increase in critical drainage area which produces greater runoff sufficient to cause incision (Poesen et al., 2003). However, steep slopes can produce greater runoff than gentle slopes given climatic conditions and surface crusting rate (Valentin et al., 2005), which is likely the case in catchment W55. 
A significant influence of KMG on gully distribution in catchment W55 is attributed to overgrazing which is evidenced by the degradation status of this grassland region, bare soil and moderate vegetation cover (moderate and moderate to high NDVI). The degradation of KMG and associated gullies were mainly observed in areas of communal land often associated with higher stocking rates, higher population densities, lower basal cover and more bare ground than commercial farmland (e.g. Vetter et al., 2006). Degraded grassland represents areas where soils are frequently disturbed, probably due to overgrazing and trampling effects as observed elsewhere in SA (Liggitt and Fincham, 1989; Le Roux and Sumner, 2012). In contrast, gullies in catchment X12 are largely influenced by cultivation, which plays a role in reducing vegetation cover and soil disturbance and thus gully initiation. Other factors may also have played a role including rainfall erosivity which is the main driver of water erosion processes. Although rainfall erosivity values are lower on areas where gullies dominate in both catchments, when coupled with lower vegetation cover due to other disturbances and susceptible soils (e.g. overgrazing and cultivation), their role on gully erosion becomes significant.

\section{Conclusion}

In this study, a combination of GIS and statistical InfVal weight were used to assess, quantify and compare the influence of various factors (geology, soil, topography, vegetation type and cover, rainfall erosivity and land use) contributing to gully erosion from catchments W55 and X12. Gully erosion features were mapped in a GIS by means of manual digitizing with the results indicating that gullies of different sizes and densities affect $0.6 \%$ of catchment X12 and $0.2 \%$ of catchment W55. A GIS overlay analysis of the gully map and contributing factors data 
(secondary and data derived for this study) allowed for the independent assessment of the influence of each factor.

Catchment W55 is predisposed to gully erosion due to the underlying Randian age granite rocks which gave rise to very deep Hutton soil form with variable texture. Gully erosion propensity increases rapidly for hillslopes steeper than $4.5^{\circ}$. The slope greater than $4.5^{\circ}$ is particularly vulnerable when there is high enough energy to entrain sediments, where overland flow converges and accumulates. Overgrazing also played a role of reducing protective vegetation cover and in some cases leaving the ground bare and thus enhancing gully formation.

Three geological substrates in catchment X12 gave rise to the materials susceptible to gully erosion. First is the granite and gneiss rocks overlain by medium shallow duplex Estcourt soil form with loam texture. Second is the Quaternary unconsolidated sediments marked by oxidic (Hutton and Shortlands forms), duplex (Swartland form) and lithic (Glenrosa form) soil groups which are deep to very deep and have clay texture. Third is the ultramafic rocks characterized by oxidic (Hutton, Shortlands and Clovelly forms), duplex (Swartland form), vertic (Arcadia form) and melanic (Bonheim and Mayo forms) soil groups with patches of lithosols. These soils have depth ranging from very shallow to medium shallow and have loam and clay texture. Land use factor such as cultivation played a significant part in reducing vegetation cover and enhancing erodibility. A topographical threshold for gully erosion is marked by nearly flat to strongly sloping landscapes where overland flow converges, accumulates and soil is moister with stream power varying from low and high.

From this observation, it is clear that gully erosion is influenced by a wide range of factors including those previously regarded as insignificant such as oxidic soils with stabilizing iron oxides. Knowledge of contributing factors is important when developing models to predict area 
that may currently be gully free but have high potential for gully erosion development. Any future modelling should note that different areas have different erodibilities due to the heterogeneity of the landscape and the interaction of both environmental and land use factors. Therefore, modelling of gullies based on the factors controlling their formation should be able to adapt to local conditions.

\section{Acknowledgements}

We wish to thank the University of Pretoria and the Department of Agriculture, Forestry and Fisheries for financial assistance to this research as well as the Department of Agriculture, Rural Development, Land and Environmental Affairs for provision of data and software. Our gratitude to the journal editor (Takashi Oguchi), GA Botha and anonymous reviewer for their inputs.

\section{References}

Beckedahl, H.R., 1977. Subsurface erosion near the Oliviershoek Pass, Drakensberg. South African Geographical Journal 59, 130-138. doi:10.1080/03736245.1977.10559582.

Bradford, J.M., Piest, R.F., 1980. Erosional development of valley-bottom gullies in the upper midwestern United States, in: Coates, D.R., Vitek, J.D. (Eds.), Geomorphic Thresholds. Dowden and Culver, Stroudsburg, Pennyslvania, pp. 75-101.

Bühmann, C., Schoeman, J.L., 1995. A mineralogical characterization of vertisols from the northern regions of the Republic of South Africa. Geoderma 66, 239-257.

Casali, J., Gimenez, R., Bennett, S., 2009. Gully erosion processes : monitoring. Earth Surface Processes and Landforms 34, 1839-1840. doi:10.1002/esp.1867.

Chaplot, V., Brown, J., Dlamini, P., Eustice, T., Janeau, J.L., Jewitt, G., Lorentz, S., Martin, L., Mchunu, C.N., Oakes, E., Podwojewski, P., Revil, S., Rumpel, C., Zondi, N., 2011. Rainfall simulation to identify the stormscale mechanisms of gully bank retreat. Agricultural Water Management, 98, 1704 - 1710. 
Conforti, M., Aucelli, P.P.C., Robustelli, G., Scarciglia, F., 2011. Geomorphology and GIS analysis for mapping gully erosion susceptibility in the Turbolo stream catchment (Northern Calabria, Italy). Natural Hazards 56, 881-898. doi:10.1007/s11069-010-9598-2.

Dardis, G.F., Beckedahl, H.R., 1991. The role of rock properties in the development of bedrock-incised rills and gullies: examples from southern Africa. GeoJournal 23, 35-40.

Duncan, P., Smit, J., 2013. Investigating automatic change detection of topographic features. Position IT 47-52.

Elges, H.F.W.K., 1985. Dispersive soils: problem soils in South Africa - state of the art. The Civil Engineer in South Africa 27, 347-353.

Fey, M.V., 2009. Soils of South Africa. Stellenbosch University, Stellenbosch.

Fourie, A., 2009. Better crop estimates in South Africa: integrating GIS with other business systems. Arcuser 26-27.

Gabris, G.Y., Kertesz, A., Zambo, L., 2003. Land use change and gully formation over the last 200 years in a hilly catchment. Catena 50, 151-164.

Geological Survey, 1986a: 2630 Mbabane, 1:250 000 Geological Series. Department of Mineral and Energy Affairs, Pretoria.

Geological Survey, 1986b: 2530 Barberton, 1:250 000 Geological Series. Department of Mineral and Energy Affairs, Pretoria.

Grellier, S., Kemp, J., Janeau, J.L., Florsch, N., Ward, D., Barot, S., Podwojewski, P., Lorentz, S., Valentin, C., 2012. The indirect impact of encroaching trees on gully extension: a 64 year study in a sub-humid grassland of South Africa. Catena, 98, $110-119$.

Hancock, G.R., Evans, K.G., 2006. Channel head location and characteristics using digital elevation models. Earth Surface Processes and Landforms 31, 809-824. doi:10.1002/esp.1285.

Imasuen, O.I., Omali, A.O., Ibrahim, I., 2011. Assessment of environmental impacts and remedies for gully erosion in Ankpa Metropolis and environs, Kogi State, Nigeria. Advances in Applied Science Research 2, 372-384.

Jahantigh, M., Pessarakli, M., 2011. Causes and effects of gully erosion on agricultural lands and the environment. Communications in Soil Science and Plant Analysis 42, 2250-2255. doi:10.1080/00103624.2011.602456.

Kakembo, V., Xanga, W.W., Rowntree, K., 2009. Topographic thresholds in gully development on the hillslopes of communal areas in Ngqushwa Local Municipality, Eastern Cape, South Africa. Geomorphology 110, $188-194$. doi:10.1016/j.geomorph.2009.04.006. 
Laker, M.C., 2004. Advances in soil erosion, soil conservation, land suitability evaluation and land use planning research in South Africa, 1978 - 2003. South African Journal of Plant and Soil 21, 345-368.

Lal, R., 2001. Soil degradation by erosion. Land Degradation and Development 12, 519-539. doi:10.1002/ldr.472.

Le Roux, J.J., Morgenthal, T.L., Malherbe, J., Pretorius D.J., Sumner, P.D., 2008. Water erosion prediction at a national scale for South Africa. Water SA 34, 305-314.

Le Roux, J.J., Morgenthal, T.L., Malherbe, J., Smith, H.J., Weepener, H.L., Newby, T.S., Pretorius, D.J., 2006. Improving spatial soil erosion indicators in South Africa. ARC-ISCW Report No. GW/A/2006/51, Pretoria.

Le Roux, J.J., Sumner, P.D., 2012. Factors controlling gully development: comparing continuous and discontinuous gullies. Land Degradation and Development 23, 440-449. doi:10.1002/ldr.1083.

Liggitt, B., Fincham, R.J., 1989. Gully erosion: the neglected dimension in soil erosion research. South African Journal of Science 85, 18-20.

Luca, F., Conforti, M., Robustelli, G., 2011. Comparison of GIS-based gullying susceptibility mapping using bivariate and multivariate statistics : Northern Calabria, South Italy. Geomorphology 134, 297-308. doi:10.1016/j.geomorph.2011.07.006.

Lyons, R., Tooth, S., Duller, G.A.T., 2013. Chronology and controls of donga (gully) formation in the upper Blood River catchment, KwaZulu-Natal, South Africa : Evidence for a climatic driver of erosion. The Holocene 23, 1875-1887. doi:10.1177/0959683613508157.

Manjoro, M., Rowntree, K., Kakembo, V., Foster, I.D.L., 2012. Gully fan morphodynamics in a small catchment in the Eastern Cape, South Africa. Land Degradation and Development 23, 569-576. doi:10.1002/ldr.2174.

Mararakanye, N., Le Roux, J.J., 2012. Gully location mapping at a national scale for South Africa. South African Geographical Journal 94, 208-218. doi:10.1080/03736245.2012.742786.

Mararakanye, N., Nethengwe, N.S., 2012. Gully erosion mapping using remote sensing techniques in the Capricorn District, Limpopo. South African Journal of Geomatics 1, 109-118.

Marker, M., Sidorchuk, A., 2003. Assessment of gully erosion process dynamics for water resources management in a semiarid catchment of Swaziland (Southern Africa), in: Erosion Prediction in Ungauged Basins: Integrating Methods and Techniques (Proceedings of Symposium HS01 Held during IUGG2003 at Sapporo, July 2003). IAHS Publications, pp. 188-198. 
Mathis, J.E., 2007. Specific catchment area as a basis of design for precision riparian buffers, in: Proceedings of the 2007 Georgia Water Resources Conference, Held March 27-29, 2007, at the University of Georgia. pp. 1-4.

Middleton B.J., Bailey A.K., 2008. Water Resources of South Africa, 2005 study. Water Research Commission Report Number TT 381/08, Pretoria.

Midgley D.C. Pitman W.V., Middleton B.J., 1994. Surface Water Resources of South Africa 1990: User's Manual. Water Resource Commission Report no. 298/1/94, Pretoria.

Mucina, L., Rutherford, M.C. (Eds.), 2006: The vegetation of South Africa, Lesotho and Swaziland. Strelitzia 19. South African National Biodiversity Institute (SANBI), Pretoria.

Nandi, A., Shakoor, A., 2009. A GIS-based landslide susceptibility evaluation using bivariate and multivariate statistical analyses. Engineering Geology 110, 11-20. doi:10.1016/j.enggeo.2009.10.001.

National Land Cover, 2000: Unpublished database. ARC-Institute for Soil, Climate and Water; Council for Scientific and Industrial research, Pretoria.

Nwilo, P.C., Olayinka, D.N., Uwadiegwu, I., Adzandeh, A.E., 2011. An assessment and mMapping of gully erosion hazards in Abia State : a GIS approach. Journal of Sustainable Development 4, 196-211. doi:10.5539/jsd.v4n5p196.

Oldeman, L.R., 1993. An international methodology for assessment of soil degradation and georeferenced soils and terrain database, in: Third Expert Consultation of the Asian Network of Problem Soils, Bangkok, Thailand, 2529 October 1993. International Soil Reference and Information Centre, Wageningen, pp. 1-22.

Poesen, J., Nachtergaele, J., Verstraeten, G., Valentin, C., 2003. Gully erosion and environmental change : importance and research needs. Catena 50, 91-133.

Poesen, J.W., Vandaele, K., Van Wesemael, B., 1996. Contribution of gully erosion to sediment production on cultivated lands and rangelands, in: Erosion and Sediment Yield: Global and Regional Perspectives (Proceedings of the Exeter Symposium, July 1996). IAHS Publications, pp. 251-266.

Pradhan, B., Chaudhari, A., Adinarayana, J., Buchroithner, M.F., 2012. Soil erosion assessment and its correlation with landslide events using remote sensing data and GIS : a case study at Penang Island, Malaysia. Environmental Monitoring and Assessment 184, 715-727. doi:10.1007/s10661-011-1996-8.

Rautela, P., Lakhera, R.C., 2000. Landslide risk analysis between Giri and Tons Rivers in Himachal Himalaya (India). International Journal of Applied Earth Observations and Geoinformation 2, 153-160. 
Rienks, S.M., Botha, G.A., Hughes, J.C., 2000. Some physical and chemical properties of sediments exposed in a gully (donga) in northern KwaZulu-Natal, South Africa and their relationship to the erodibility of the colluvial layers. Catena 39, 11-31. doi:10.1016/S0341-8162(99)00082-X

Rooseboom A., Verster E., Zietsman H.L., Lotriet H.H., 1992. The development of the new Sediment Yield Map of South Africa, Water Research Commission Report no. 297/2/92, Pretoria.

Salleh, K.O., Mousazadeh, F., 2011. Gully erosion in semiarid regions, in: Procedia - Social and Behavioral Sciences (The 2nd International Geography Symposium GEOMED2010). Elsevier Ltd, pp. 655-661. doi:10.1016/j.sbspro.2011.05.182.

Soil Classification Working Group, 1991. Soil Classification: A taxonomic system for South Africa, Memoirs on the Agricultural Natural Resources of South Africa No. 15. Department of Agricultural Development, Pretoria.

Sonneveld, M.P.W., Everson, T.M., Veldkamp, A., 2005. Multi-scale analysis of soil erosion dynamics in KwazuluNatal, South Africa. Land Degradation and Development 16, 287-301. doi:10.1002/Ldr.653.

Stocking, M., Murnaghan, N., 2000. Land degradation - guidelines for field assessment. Overseas Development Group, University of East Anglia, Norwich.

Tarboton, D.G., 1997. A new method for the determination of flow directions and upslope areas in grid digital elevation models. Water Resources Research 33, 309-319.

Tarboton, D.G., Mohammed, I.N., 2013. TAUDEM 5.1: quick start guide to using the TAUDEM ArcGIS toolbox. Utah State University (USU), Utah.

Thiemann, S., Schütt, B., Förch, G., 2005. Assessment of erosion and soil erosion processes - a case study from the northern Ethiopian Highland, in: Topics of Integrated Watershed Management - Proceedings. FWU, pp. 173185.

Tobler, W., 1988. Resolution, resampling, and all that, in: Mounsey, H., Tomlinson, R. (Eds.), Building Data Bases for Global Science. Taylor and Francis, London, pp. 127-137.

Valentin, C., Poesen, J., Li, Y., 2005. Gully erosion : impacts, factors and control. Catena 63, 132-153. doi:10.1016/j.catena.2005.06.001.

Van den Berg, H.M., 2000. The mapping of soil patterns by means of remote sensing and multi-layer modelling in a GIS. ARC-ISCW report, Pretoria. 
Van Niekerk, A., 2012. Stellenbosch University Digital Elevation Model (SUDEM) 2011 Edition. Centre for Geographical Analysis, Stellenbosch University, Stellenbosch.

Van Westen, C.J., 1993. Application of geographic information systems to landslide hazard zonation. ITC publ. no. 15, International Institute for Aerospace Survey and Earth Sciences (ITC), Enschede.

Van Westen, C.J., Rengers, N., Terlien, M.T.J., Soeters, R., 1997. Prediction of the occurrence of slope instability phenomena through GIS-based hazard zonation. Geologische Rundschau 86, 404-414.

Vandekerckhove, L., Poesen, J., Wijdenes, D.O., Gyssels, G., Beuselinck, L., De Luna, E., 2000. Characteristics and controlling factors of bank gullies in two semi-arid Mediterranean environments. Geomorphology 33, 37-58.

Vanwalleghem, T., Poesen, J., Nachtergaele, J., Verstraeten, G., 2005. Characteristics, controlling factors and importance of deep gullies under cropland on loess-derived soils. Geomorphology 69, 76-91. doi:10.1016/j.geomorph.2004.12.003.

Vetter, S., 2007. Soil erosion in the Herschel District of South Africa: changes over time, physical correlates and land users' perceptions. African Journal of Range and Forage Science 24, 77-86. doi:10.2989/AJRFS.2007.24.2.4.158.

Vetter, S., Goqwana, W.M., Bond, W.J., Trollope, W.W., 2006. Effects of land tenure, geology and topography on vegetation and soils of two grassland types in South Africa. African Journal of Range and Forage Science 23, 13-27. doi:10.2989/10220110609485883.

Vorster, P.J., 2003. The development of South African Topographic Information System, in: Proceedings of the 21st International Cartographic Conference (ICC), 10 - 16 August 2003. Document Transformation Technologies, pp. 1460-1473.

Vrieling, A., 2006. Satellite remote sensing for water erosion assessment : a review. Catena 65, 2-18. doi:10.1016/j.catena.2005.10.005.

Watson, H.K., 2000. Land reform implications of the distribution of badlands in the Mfolozi catchment, KwazuluNatal. South African Geographical Journal 82, 143-148. doi:10.1080/03736245.2000.9713706.

Watson, H.K., Ramokgopa, R., 1997. Factors influencing the distribution of gully erosion in Kwazulu Natal's Mfolozi catchment—land reform implications. South African Geographical Journal 79, 27-34. doi:10.1080/03736245.1997.9713619. 
Watson, H.K., Ramokgopa, R., Looser, U., 1996. The distribution of erosion in the Mfolozi drainage basin implications for sediment yield control, in: Erosion and Sediment Yield: Global and Regional Perspectives (Proceedings of the Exeter Symposium, July 1996). IAHS Publications, pp. 357-366.

Wessels, K.J., Prince, S.D., Frost, P.E., Van Zyl, D., 2004. Assessing the effects of human-induced land degradation in the former homelands of northern South Africa with a $1 \mathrm{~km}$ AVHRR NDVI time-series. Remote Sensing of Environment 91, 47-67. doi:10.1016/j.rse.2004.02.005.

Wilson, J.P., Gallant, J.C., 2000. Digital terrain analysis, in: Wilson, J.P., Gallant, J.C. (Eds.), Terrain Analysis: Principles and Applications. John Wiley \& Sons Ltd, New York, pp. 1-27.

Yu, B., Rosewell, C.J., 1996. A robust estimator of the R-factor for the Universal Soil Loss Equation. American Society of Agricultural Engineers 39, 559-561.

Zevenbergen, L.W., Thorne, C.R., 1987. Quantitative analysis of land surface topography. Earth Surface Processes and Landforms 12, 47-56.

Zezere, J.L., 2002. Landslide susceptibility assessment considering landslide typology: a case study in the area north of Lisbon (Portugal). Natural Hazards and Earth System Sciences 2, 73-82. 